\title{
Student Perceptions of Effective English Language Teachers A Quantitative Study - Republic of Panama
}

\author{
Mónica León ${ }^{1 *}$, Ian Neblett ${ }^{2 *}$ \\ ${ }^{1}$.English Program Director, Quality Leadership University, Panama City, Panama \\ 2. Teaching Assistant, Quality Leadership University, Panama City, Panama \\ * Autor para correspondencia. Email:mleon@qlu.pa, ianneblett@hotmail.com
}

Recibido: 27 de julio de 2018

Aceptado: 14 de agosto de 2018

\begin{abstract}
Views of surveyed English language learners attending, or who had previously attended, EFL classes in Quality Leadership University, were analyzed in this study. A total of 150 students from the English program took part in the study. The researchers were interested in extracting perspectives on what students believed to be an effective English teacher. As previously mentioned, data was gathered via a survey. The survey contained a total of 13 questions, of which the last question had 45 prompts to respond to in a Likert-styled scale. Results of the survey were grouped into predetermined, categories of significance, analyzed and confirmed for congruency. The results revealed student's affinity towards English language teachers who possessed key attributes. Our research, which has been corroborated by prior studies, establishes a point of reference and additional insight into the definition of an effective English language teacher.
\end{abstract}

Keywords: Teaching English, English, Student Satisfaction, Student Perceptions, Effective English Language Teachers.

\section{Resumen}

El presente estudio se analizó las opiniones de los estudiantes de inglés encuestados que asistieron o que habían asistido anteriormente a las clases de EFL en Quality Leadership University. Un total de 150 estudiantes del programa de inglés participaron en el estudio. Los investigadores estaban interesados en extraer perspectivas sobre lo que los estudiantes creían que era un profesor de inglés efectivo. Como se mencionó anteriormente, los datos se recopilaron a través de una encuesta. La encuesta contenía un total de 13 preguntas, de las cuales la última pregunta tenía 45 pautas para responder en una escala de estilo Likert. Los resultados de la encuesta se agruparon en categorías predeterminadas de significancia, se analizaron y se confirmaron por congruencia. Los resultados revelaron la afinidad del estudiante hacia los profesores de inglés que poseían atributos clave. Nuestra 
Invest. pens. crit. (ISSN 1812-3864)

Vol. 6, No. 2, mayo - agosto 2018

pp. 13-29

investigación, que ha sido corroborada por estudios previos, establece un punto de referencia y una visión adicional de la definición de un maestro de inglés efectivo.

Palabras clave: Enseñanza del inglés, inglés, satisfacción estudiantil, percepción estudiantil, docente de inglés eficiente.

\section{Introduction}

There is legitimate interest from institutions that offer English classes as a foreign language to discover what students really consider important when it pertains to identifying the attributes of an effective English teacher (Barnes \& Lock, 2010). Previous studies have revealed various attributes and positions of rank among those attributes, in which the variation sometimes depended on the group of students analyzed. Albeit, there are some recurring variables among most student's preferences and the way they perceive teacher's effectiveness in teaching. These variables suggest a more student-centered approach (Salahshour, N. \& Hajizadeh, N., 2012), where all efforts of the learning experience are directed towards the primary stakeholder of the classroom: the student.

Hence, this study aims to shed light on the following questions:

1. What are the student's perceptions of effective English Language teachers?

2. Are there any differences among age groups, gender, and levels of English?

With respect to those perceptions, we expect a little variation from other previous studies due to cultural differences, but we are uncertain whether it will vary between genders. Understanding the necessity to study English may factor into the evaluation as well, as it tends to be of more importance to adults. It would also be a mistake not to take into account preferred learning styles among both groups: younger students and adults.

We also believe that students' perceptions of effective English language teachers will rank higher on rapport (i.e. friendliness, sociability, empathy, accessibility, receptiveness, and attitude), and delivery (i.e. personal style, communication and pedagogy), as it was previously uncovered from a study conducted in a Korean university (Barnes and Lock, 2013). Rapport and delivery may also be significant factors due to the student's inherent fear of using the language in a preconceived, judgmental environment.

In addition to the study in Korea, there has been research conducted in Europe, the Middle East, and in the United States. Albeit, there is no existent, published, research based in the Republic of Panama or its surrounding countries.

This study intends to contribute much needed information in an unexplored territory, in the matter of students' perceptions of effective English language teaching. Our purpose is to provide interested parties the ability to compare and contrast what is happening in Panama, with the existing tendencies in the field of EFL education that has already been explored. We are hoping that this will be the starting point for teachers to revisit, or discover some of the key elements that strengthen teaching practices and improve the probability of successful language acquisition. Further, we are eager to provide a guideline of key elements teachers need to accomplish in order to meet student's lofty expectations. 
Invest. pens. crit. (ISSN 1812-3864)

Vol. 6, No. 2, mayo - agosto 2018

pp. 13-29

Overall, we are confident that the outcome of this study will contribute to the EFL education goals in our country. We have also considered the possible needs of the surrounding Latin American countries, and believe the information could be of value to them as well. The goal of closing the gap, or discovering what the gap is between the current learning environment and student expectations, should always be a sought after endeavor in all subject matters.

\section{Literature Review}

While the discovery of students' perceptions, with respect to identifying the key traits which define an effective English language teacher is our primary focus, we can't ignore the preconceived influences teachers and educational systems have already established. While students seem to be more concerned with the soft-skills teachers should possess or could possibly obtain, teachers have mostly preoccupied themselves with the hard-skills related to teaching methods and lesson execution. Case in point, EFL teachers located in countries such as Mexico, Brunei, Malaysia, Thailand, Indonesia, Cambodia, and Vietnam have reportedly held strict allegiance to traditional instructional methods (Maskhao, 2002, Liu, 2004; Nonkukhethong et al., 2006; Darasawang, 2007; Davies, 2009; Khamkhien, 2010; Yamat et al., 2014; Richer \& Herrera 2014). It goes without saying that the types of methods which embody the traditional approach are in stark contrast to the student-centered approach. This study analyzes the types of characteristics that would lean towards and promote the latter approach.

That being said, the tide is slowly changing in the English language learning environment. As the exchange of information increases across a variety of platforms (i.e. the Internet, international programs and events), improved techniques are being exchanged, considered, and increasingly adopted. These baby steps towards teaching excellence seem to indicate a positive stride in professional practice (Darasawang, 2007; Chepetla et al., 2008; Khamkhien, 2010; Othman, 2010; Ramirez-Romero and Pamplon, 2012), and towards a more student-centered environment.

Latin America, which has a tremendous degree of importance in our research, has begun to progress from audio-lingual methods to more modernized teaching practices and pedagogical techniques (Anderson, 2012). Mexico, which is a big player in the ELL market, had suffered from broken educational systems in the past due to their reluctance to advance beyond the traditional methods (Davies 2009), to now conducting teacher preparation programs, promoting professional associations, and even championing the movement towards cutting edge approaches to language pedagogy. To that end, the Panamanian government has also become aggressive in amplifying the quality of English education in the public school system by sending English teachers abroad to glean best practices in lesson planning, lesson execution, and assessment strategies. There are many other efforts being conducted in the Latin American region, and they all bode well for the English teacher and student alike. The countries in the region are beginning to understand and appreciate the necessity of English language learning, and are taking the necessary steps to achieve that end. As countries expedite the preparation of teachers in order to enhance in-classroom performance, they must likewise investigate the expectations of the students. Efforts on one end, while leaving the other undone could result in costly missed opportunities, and underachievement of both the teachers and their students. 
Invest. pens. crit. (ISSN 1812-3864)

Vol. 6, No. 2, mayo - agosto 2018

pp. 13-29

In light of that, endeavors to discern student expectations have already begun in other parts of the world. For example, a study was conducted in 2012 by Salahshour, N. \& Hajizadeh, N., in a prominent school in Tabriz, Iran, in which 42 students were surveyed. The researcher's main goal was to determine the student's perspective of an effective teacher. According the answers given, having interest in his/her job ranked highest followed by items such as having a sense of responsibility towards the job, being enthusiastic and lively, self-confident, punctual, encouraging students to use the language, and providing explicit grammar correction.

A similar study was conducted by Simpson, A. \& Mengi, E. in 2011, in Instanbul Turkey, where students were asked to provide a written response to the prompt: 'what is your perception of a good English teacher?' An additional dimension was added to that study by having teachers respond to the same prompt, as the researchers were interested in the congruency of both perspectives. After a process of data coding was conducted certain key categories emerged like methods of delivery, classroom environment, and teacher qualities. The latter category is of special interest to our efforts, because it underlines the importance of our study and the others that have been conducted with that similar focus.

A quantitative study that has served as our motivation for our research, and coincides with the immediate aforementioned was done by Barnes and Lock in 2013. Their questionnaire was circulated in a Korean university to measure the importance students' placed on 5 key categories, namely: Rapport, Delivery, Fairness, Knowledge and Credibility, and Organization and Preparation. These categories were given birth from the culmination of efforts and results carried out during a previous qualitative study in the same university, in which delivery and rapport were the focus (Barnes and Lock 2010). It was the results from the 2010 qualitative study that led to the expansion of attributes observed in the 2013 study. Barnes and Lock (2013) confirmed that students placed significant importance on most of the attributes they identified in the qualitative study. They were also enlightened to further insight pertaining to the student opinions on the use of their first language in the EFL classroom, grammar instruction, and teacher-student engagement techniques.

Our study has essentially replicated the methodology of the quantitative study conducted by Barnes and Lock, outlined in the following section.

\section{Methodology}

The research was conducted by the English as a Second Language Department of a private university in the Republic of Panama.

A questionnaire was administered to students who are or had previously studied English at the institution. The sample comprised 193 females, and 122 male students. Of those same students the majority came from the age groups $15-17$, and $24-29$. The majority of students surveyed were originally from Panama, Venezuela, and Columbia respectively.

The questionnaire was written in Spanish to assure the questions were fully understood by the respondents, thereby guaranteeing a high response rate. The first section consisted of questions related to their background, experience in English education, and their preferred learning styles. In 
Invest. pens. crit. (ISSN 1812-3864)

Vol. 6, No. 2, mayo - agosto 2018

pp. 13-29

the second part (comprised of 2 questions), the students utilized a Likert scale from 1 to 5 (5 being the most important and 1 being the least important), in order to glean their perspectives on the 'makeup' of an effective English teacher.

The responses to the second section were analyzed via the use of mean and standard deviation calculations, in order to compare and contrast what the students valued from what they had little regard for.

\section{Student Profile}

\section{English Language Proficiency}

Question 5 on our survey (see Appendix) asked the students to describe their current level of English fluency. The three options to choose from were beginning, intermediate, and advanced. Of the 315 students who responded, $173(55 \%)$ of them classified themselves as beginners, $122(39 \%)$ as intermediates, and $20(6 \%)$ as advanced learners. We assumed that students could properly assess their level of fluency due to placement tests they had to write before entering the program.

\section{Past English Language Learning Experience}

Question 8 of our survey (see Appendix) asked students to indicate whether they obtained English language training in the past from other institutions. The results revealed that out of the 311 who responded, the majority (59.8\%) of students did not have any previous training in English (i.e. from an official learning institution).

\section{Learning Styles}

Questions 11 \& 12 of our survey (see Appendix) asked students to indicate their preferred learning style. Question 11 had the options: active or passive. While question 12 had the options: visual, auditory, verbal, physical, logical, socially, and alone respectively. The results of these questions revealed slight differences between male and female respondents. While both genders preferred a more active approach to learning (47\% of females compared to 55\% of males), a larger group of females preferred a mixed approach of both active and passive (43\% of females in comparison to $37 \%$ of males). With respect to question 12 , both genders agreed that the top three preferred learning styles were: visual, auditory, and verbal respectively. However, $46 \%$ of males preferred a logical approach, while only $27 \%$ of females preferred this method. 
Invest. pens. crit. (ISSN 1812-3864)

Vol. 6, No. 2, mayo - agosto 2018

pp. 13-29

\section{Results}

The next section of the analysis begins to delineate the five key categories of teacher attributes borrowed from Faranda and Clarke (2004), and later utilized by Barnes and Lock (2010) as well. As an addition to their analysis we have considered the vantage points from both males and females. The immediate table below outlines the five categories along with their ranking of importance from a student's perspective:

Table 1.

\begin{tabular}{|c|l|c|}
\hline $\begin{array}{c}\text { Overall } \\
\text { Ranking }\end{array}$ & \multicolumn{1}{|c|}{ Attributes } & $\begin{array}{c}\text { Mean } \\
\text { Score }\end{array}$ \\
\hline 1 & Knowledge of English & 3.58 \\
\hline 1 & Communication skill and teaching method (i.e. Delivery) & 3.58 \\
\hline 2 & $\begin{array}{l}\text { Relationship with students (personality, care, } \\
\text { understanding) }\end{array}$ & 3.11 \\
\hline 3 & Organization and preparation & 2.83 \\
\hline 4 & $\begin{array}{l}\text { Fairness (regarding general treatment of students and } \\
\text { assessment) }\end{array}$ & 2.28 \\
\hline
\end{tabular}

Table 1: Overall Ranking of Categories/Attributes - Effective Foreign Language Teacher

As the chart above indicates, Knowledge of English and Communication Skill and Teaching Method (i.e. Delivery style) both ranked equally the highest with our students (3.58 mean score), and Relationship with students (i.e. Rapport) ranked second with a mean score of 3.11. There were differences, however, with respect to genders among the attributes. For example a higher proportion of females thought Knowledge of English was very important, which was demonstrated by the fact that $22.9 \%$ and $37.1 \%$ of the female respondents indicated that this attribute was the second, and most important respectively. On the other hand, the males were a little more evenly spread on our Likert scale (1 being of least importance and 5 most important): 3.7\%, 22.2\%, 23.1\%, 22.2\%, and 28.7\% respectively.

As mentioned in the introduction, our survey contained a total of 13 questions, of which the last question had 45 prompts to respond to in a Likert-styled scale. The tables illustrated below reveal the results to those prompts on a scale from 1 to 5 (in mean scores), where 1 was considered least important and 5 was the considered the most important. The prompts below were then group together according to the appropriate categories analyzed in table 1. The prompts, and titles of the columns contained in the tables closely mirror that of the study conducted by Barnes and Lock (2013). This strategy was purposely taken in order to compare and contrast the results from a Latin American and gender specific perspective. 
Invest. pens. crit. (ISSN 1812-3864)

Vol. 6, No. 2, mayo - agosto 2018

pp. 13-29

\section{Relationship with Students (Rapport)}

Almost all elements of the rapport attribute were considered important (i.e. scored 4 and above) according to our results, with the exception of a teacher's willingness to share experiences (See Table 2).

\begin{tabular}{|l|c|c|}
\hline \multicolumn{1}{|c|}{ Item Number and Description } & M & SD \\
\hline 1. are friendly & 4.28 & 0.82 \\
\hline 2. develop good relationships with students & 4.18 & 0.84 \\
\hline 3. share personal experiences & 3.65 & 1.05 \\
\hline 4. care about students & 4.24 & 0.82 \\
\hline 5. are patient & $\mathbf{4 . 3 3}$ & $\mathbf{0 . 8 5}$ \\
\hline 6. listen to students & $\mathbf{4 . 3 8}$ & $\mathbf{0 . 7 9}$ \\
\hline 7. have a positive attitude in general & $\mathbf{4 . 4 3}$ & $\mathbf{0 . 7 8}$ \\
\hline 8. have charisma & 4.25 & 0.81 \\
\hline 9. understand the student's English background & 4.17 & 0.86 \\
\hline 10. understand the different student levels & 4.25 & 0.88 \\
\hline 11. have a sense of humor & 4.04 & 0.95 \\
\hline
\end{tabular}

Table 2: Mean Scores and Standard Deviations for Rapport Prompts

Our results, however, did not coincide with Frananda and Clarke (2004), Thompson (2006), or Barnes and Lock (2013), in which the attribute 'develop good relationships with students' garnered the highest levels of importance. The Latin American student appears to be different in this aspect of rapport, in determining teachers' effectiveness. Our students believe a positive attitude is the most important, followed by a teacher who listens to their students concerns/issues, and those who are patient. These results are not surprising considering the fact that these top three elements would go a long way in managing affective filters. Filters such as fear, nervousness, boredom, and resistance to change do need to be addressed in order to promote successful language acquisition (Krashen, 1982).

\section{Delivery}

According to our quantitative data we had many elements under the attribute of delivery register as fairly important for our Latin American students (see Table 3). Most notably, according to our results, a teacher who actively corrects student's speaking and writing errors tallied the highest and third highest respectively. A teacher's ability to activate student participation in the classroom ranked the second highest under this attribute. These results are surprising when motivation to learn a second language is put into the equation (Shaaban \& Ghaith, 2008).

\begin{tabular}{|l|c|c|}
\hline \multicolumn{1}{|c|}{ Item Number and Description } & M & SD \\
\hline 12. are enthusiastic about teaching English & 4.47 & 0.78 \\
\hline 13. give clear explanations & 4.42 & 0.89 \\
\hline
\end{tabular}


Invest. pens. crit. (ISSN 1812-3864)

Vol. 6, No. 2, mayo - agosto 2018

pp. 13-29

\begin{tabular}{|l|l|l|}
\hline 14. use good examples & 4.41 & 0.81 \\
\hline 15. use a variety of teaching methods & 4.32 & 0.89 \\
\hline 16. use Spanish (L1) selectively & 3.35 & 1.31 \\
\hline 17. use Spanish to clarify and explain English classes & 3.06 & 1.41 \\
\hline 18. use English in class only & 3.68 & 1.25 \\
\hline 19. correct writing errors & 4.48 & 0.83 \\
\hline 20. correct speaking errors & 4.50 & 0.85 \\
\hline 21. teach grammar & 4.46 & 0.82 \\
\hline 22. use group work & 4.39 & 0.82 \\
\hline 23. encourage student participation in class & 4.49 & 0.77 \\
\hline $\begin{array}{l}\text { 24. encourage participation of students with low } \\
\text { confidence }\end{array}$ & 4.37 & 0.89 \\
\hline 25. talk slowly in the target language & 3.76 & 1.13 \\
\hline 26. use easy words (to enhance understanding) & 3.98 & 0.95 \\
\hline 27. ask questions frequently & 4.22 & 0.88 \\
\hline 28. ask questions then wait for volunteers to answer & 4.24 & 0.83 \\
\hline 29. ask individual students to answer questions & 4.24 & 0.88 \\
\hline 30. give students plenty of time to answer questions & 4.16 & 0.88 \\
\hline
\end{tabular}

Table 3: Mean Scores and Standard Deviations for Delivery

Another element with high distinction in this category is teachers who are enthusiastic about teaching English. This sentiment seems to be shared by many students around the world because its importance is in harmony with American business students (Faranda \& Clarke, 2004; Desai et al., 2001; Kelley et al., 1991) and Korean students (Barnes and Lock, 2013). Other soft skills that scored high among the students were encouraging student participation, and encouraging students with low confidence to participate in classroom activities. On the other hand, other technical skills which had scores of significance were the teacher's ability to give clear explanations, use good examples, teach grammar, and facilitate group work.

To our surprise using Spanish (L1) selectively, using Spanish to clarify and explain English classes, and only using English in class had average importance to our students 3.35, 3.06, 3.68 respectively. The latter two elements were not included in the Barnes and Lock (2013) study, but we decided to include them to see if further analysis could have explained prior unexpected results in this category. Further research needs to be conducted regarding the use of the L1 in a L2 environment because published findings seem to be inconsistent. Case in point: the research conducted by Auerbach \& Burgess (1985) and Levine (2003) revealed high scores for selective L1 usage in the classroom.

\section{Fairness}

All components in this category were important for the respondents of our survey (see Table 4). While treat all students fairly scored the highest (4.35), all of the other elements were above the mean score of 4.21. 
Invest. pens. crit. (ISSN 1812-3864)

Vol. 6, No. 2, mayo - agosto 2018

pp. 13-29

\begin{tabular}{|l|c|c|}
\hline \multicolumn{1}{|c|}{ Item Number and Description } & M & SD \\
\hline 31. treat all students fairly & $\mathbf{4 . 3 5}$ & $\mathbf{0 . 9 1}$ \\
\hline 32. prepare students well for examinations & $\mathbf{4 . 3 3}$ & $\mathbf{0 . 9 0}$ \\
\hline 33. give students clear grading guidelines & 4.22 & 0.93 \\
\hline 34. require students to work hard during class & 4.31 & 0.87 \\
\hline 35. require students to do homework & 4.28 & 0.90 \\
\hline
\end{tabular}

Table 4: Mean Scores and Standard Deviations for Fairness

Our results coincide with the results of Barnes and Lock (2013), but to a lesser extent. Their results had the mean score of treat all students fairly significantly higher than the other elements, whereas our students voted to have the elements more evenly distributed with just very slight differences. With a majority of first time English learners and affective filters playing a factor it is not a surprise that students want to be treated fairly, and be well prepared for examinations.

\section{Knowledge and Credibility}

The elements in this category scored the highest among all the others (see and compare all Tables). Possessing a good knowledge of vocabulary scored the highest (4.55), while having a good knowledge of grammar and possessing the knowledge and ability to teach English were second and third respectively (see Table 5).

\begin{tabular}{|l|l|l|}
\hline Item Number and Description & M & SD \\
\hline 36. possess the knowledge and ability to teach English & 4.51 & 0.75 \\
\hline 37. have a good knowledge of grammar & 4.53 & 0.76 \\
\hline 38. have a good knowledge of vocabulary & 4.55 & 0.78 \\
\hline
\end{tabular}

Table 5: Mean Scores and Standard Deviations for Knowledge and Credibility Prompts

Although all elements were considered important in this category, it did differ from the parent study of Barnes and Lock (2013). In their study 'qualifications' (i.e. knowledge and ability) were the most important, followed by 'a good knowledge of vocabulary', and 'having a good knowledge of grammar' a distant third. As indicated in our study these elements were fairly even among our voting population.

\section{Organization and Preparation}

All elements related to the attribute of Organization and Preparation were important to our respondents. Each element had a mean score above 4, with teachers being well prepared every lesson ranking the highest with a mean of 4.43 (see Table 6). 
Invest. pens. crit. (ISSN 1812-3864)

Vol. 6, No. 2, mayo - agosto 2018

pp. 13-29

\begin{tabular}{|l|l|l|}
\hline \multicolumn{1}{|c|}{ Item Number and Description } & \multicolumn{1}{|c|}{ M } & \multicolumn{1}{|c|}{ SD } \\
\hline 39. are well prepared every lesson & 4.43 & 0.83 \\
\hline $\begin{array}{l}\text { 40. provide a syllabus detailing course content } \\
\text { 41. explain the instructional methods to the class }\end{array}$ & 4.24 & 0.99 \\
\hline $\begin{array}{l}\text { 42. tell students the lesson objectives before each } \\
\text { lesson }\end{array}$ & 4.30 & 0.86 \\
\hline $\begin{array}{l}\text { 43. follow the syllabus } \\
\text { 44. make their own supplemental material }\end{array}$ & 4.29 & 0.95 \\
\hline 45. start and finish the class on time & 4.30 & 0.85 \\
\hline
\end{tabular}

Table 6: Mean Scores and Standard Deviations for Organization and Preparation Prompts

Overall, these mean scores indicate an appreciation on behalf of the students to have a well-structured English program. From lesson creation to schedule adherence, students want to see that the teacher is competent (see Table 5) enough to organize all necessary materials, while being an effective time manager. Once again, these results concurred with those observed by Barnes and Lock (2013), where teachers being well prepared every lesson ranked the highest as well.

\section{Discussion}

This study utilized and mirrored the research conducted by Barnes and Lock (2013). They attempted to investigate 'student perceptions of effective foreign language teachers' with a quantitative analysis. The differences between our study and theirs were the locations, the cultural backgrounds of the respondents, the added variable of gender specificity, and three extra elements for students to respond to in the questionnaire (items 17, 18, 45). Our study was conducted in the Republic of Panama, while our source investigation was conducted in Korea. As the project progressed, we became keenly interested in determining whether cultural norms and backgrounds would become a differing factor pertaining to student's perceptions of an effective foreign language teacher. Our research team were also interested in the role that gender played in deciding preferences towards teaching methods, hence our inclusion of this factor in our investigation. And lastly, the three extra elements we included were meant to uncover possible hidden propensities or inclinations with respect to the attributes of 'Organization and Preparation' and 'Delivery'.

First and foremost, our outcomes confirm that teacher competency is exceedingly important for Latin American students. Our students want to know that their instructor has a superior handle on English Grammar, possesses versatility with respect to their lexicon, and has obtained the appropriate training to facilitate and instruct the subject matter at hand. These results serve as a reminder to teachers and professors in our region to begin and/or maintain their pursuit of mastery over the profession of teaching English as a foreign language. It is also a forceful admonition to those who are currently in the profession simply because they are from a native speaking country. Although they may possess the vocabulary language learners are seeking, their deficiencies' in the other two factors will eventually be exposed if proper training and preparation are not taken seriously. 
Invest. pens. crit. (ISSN 1812-3864)

Vol. 6, No. 2, mayo - agosto 2018

pp. 13-29

The results also have implications with respect to teaching delivery. Similar to the results Barnes and Lock (2013) revealed, we found that teachers need to be visually enthusiastic about teaching as well. Unfortunately, this is not something that can be learned in a classroom, but it can be staged if the trait is lacking in a teacher's innate personality. Considering the complications that affective filters present (Krashen, 1982), it is essential that enthusiasm about teaching be a consistent trait in a teacher's repertoire in order to create an environment most conducive for learning. Additionally, and very much connected to the first discussion about competency, the ability to correct speaking and writing errors, provide good examples, give clear explanations, and encourage participation are considered important by most respondents. These key elements associated with the delivery attribute go handin-hand with the attribute of knowledge and credibility. It would be difficult to imagine a situation where a teacher was fully qualified, had good knowledge of grammar, and an expansive lexicon, but could not perform the aforementioned key elements of the delivery attribute. In fact, most of the elements of delivery would be addressed in formal training that would lead a teacher to become a qualified FL teacher. The forewarning in this matter is plain to ascertain: if a teacher lacks knowledge and credibility, classroom delivery will also be negatively affected.

This present study along with the research conducted by Barnes and Lock (2013) are in agreement with the issue of impartiality. Students from both countries (Korea and Panama) favor being treated fairly. Teachers need to be cognizant of the fact that impartiality is a non-negotiable element, especially in language learning environments where diverse levels of proficiency, experience, and preferred learning styles exist (see the Student Profile section).

As students invest their precious time to study a foreign language, teachers likewise need to dedicate time into the organization and preparation of their courses, and lesson plans. Barnes and Lock (2013) appropriately stated the fact that mutual respect and motivation can be garnered via an atmosphere predicated on thoughtful class preparation. The respondents of this questionnaire also found it important for teachers to explain instructional methods to the class, finish on time, and use supplemental material to enhance lessons. The latter two bodes well for a teacher's overall, professional image. The combination of utilizing a textbook along with interjecting other useful material demonstrates a teacher's willingness to go beyond the textbook and a dedication to his or her craft. It also shows that the teacher is trying to find ways to make the learning experience as beneficial as possible for students.

With regards to rapport (i.e. relationship building with students), the findings indicate that teachers of foreign languages in our region of the world need to have a positive attitude in general. And this positive attitude needs to extend towards being patient with the student's language acquisition process, and listening empathetically to their concerns and problems. Additionally important in the rapport category was caring for students, friendliness, having charisma, and being cognizant of different student proficiency levels. Teachers should know that most, if not all, of these traits require proactive initiative. Rapport needs to be established from the very outset of a learning period (Nilson, 2010), as this will result in a natural fulfillment of all of the elements students desire. A positive attitude, in my opinion, has appropriately ranked the highest, as this will allow the teacher to naturally be open to entertain the other elements of this attribute. 
Invest. pens. crit. (ISSN 1812-3864)

Vol. 6, No. 2, mayo - agosto 2018

pp. 13-29

\section{Conclusion}

In conclusion this study confirms many of the tenets confirmed from earlier investigations towards the definition of an effective foreign language teacher. What is important and glaringly consistent is the student's desire to be taught by qualified, credible, and knowledgeable instructors. There can be no sacrifice with respect to the attribute of knowledge because it ever so compellingly encroaches on the attribute of delivery (i.e. communication skill and teaching method). Therefore, if the former is missing then latter will be terribly insufficient, which in turn will lead to dissatisfied students seeing that these two attributes are the most important from their perspective.

Besides the aforementioned analysis there are other key takeaways from this study that teachers need to be aware of:

- Students want grammar instruction, but it needs to be incorporated with clear explanations, the utilization of a variety of teaching methods, and with engaging enthusiasm.

- Student like to be asked questions in the classroom. It helps them engage more effectively with the topic/subject being taught. However, this needs to be done in a patient, nonjudgmental, and encouraging manner.

- Students appear to want the same professionalism in EFL courses as they receive in math, science etc. This doesn't mean that they don't want a fun atmosphere, it simply means the subject needs be approached with structure (i.e. well-organized lessons, a syllabus, additional material, and properly time managed).

- While there are some differences between genders, and levels of understanding most of the key attributes are shared in importance with most students, from a variety of backgrounds.

\section{Appendix}

Table 1

\begin{tabular}{|c|c|c|c|}
\hline & Question & Mean & SD \\
\hline Item 1 & Knowledge of English & 3.11 & 1.47 \\
\hline Item 2 & Communication skill and teaching method (i.e. Delivery) & 3.58 & 1.16 \\
\hline Item 3 & Relationship with students (personality, care, \\
understanding) & 2.28 & 1.32 \\
\hline Item 4 & $\begin{array}{c}\text { Organization and preparation } \\
\text { Item 5 }\end{array}$ & Fairness (regarding general treatment of students and \\
assessment) & 3.58 & 1.31 \\
\hline
\end{tabular}


Invest. pens. crit. (ISSN 1812-3864)

Vol. 6, No. 2, mayo - agosto 2018

pp. 13-29

Table 2

\begin{tabular}{|c|c|c|c|}
\hline & Question & Mean & SD \\
\hline Item 1 & are friendly & 4.28 & 0.82 \\
\hline Item 2 & develop good relationships with students & 4.18 & 0.84 \\
\hline Item 3 & share personal experiences & 3.65 & 1.05 \\
\hline Item 4 & care about students & 4.24 & 0.82 \\
\hline Item 5 & are patient & 4.33 & 0.85 \\
\hline Item 6 & listen to students & 4.38 & 0.79 \\
\hline Item 7 & have a positive attitude in general & 4.43 & 0.78 \\
\hline Item 8 & have charisma & 4.25 & 0.81 \\
\hline Item 9 & understand the student's English background & 4.17 & 0.86 \\
\hline Item 10 & understand the different student levels & 4.25 & 0.88 \\
\hline Item 11 & have a sense of humor & 4.04 & 0.95 \\
\hline Item 12 & are enthusiastic about teaching English & 4.47 & 0.78 \\
\hline Item 13 & give clear explanations & 4.42 & 0.89 \\
\hline
\end{tabular}


Invest. pens. crit. (ISSN 1812-3864)

Vol. 6, No. 2, mayo - agosto 2018

pp. 13-29

\begin{tabular}{|c|c|c|c|}
\hline Item 14 & use good examples & 4.41 & 0.81 \\
\hline Item 15 & use a variety of teaching methods & 4.32 & 0.89 \\
\hline Item 16 & use Spanish (L1) selectively & 3.35 & 1.31 \\
\hline Item 17 & use Spanish to clarify and explain English classes & 3.06 & 1.41 \\
\hline Item 18 & use English in class only & 3.68 & 1.25 \\
\hline Item 19 & correct writing errors & 4.48 & 0.83 \\
\hline Item 20 & correct speaking errors & 4.50 & 0.85 \\
\hline Item 21 & teach grammar & 4.46 & 0.82 \\
\hline Item 22 & use group work & 4.39 & 0.82 \\
\hline Item 23 & encourage student participation in class & 4.49 & 0.77 \\
\hline Item 24 & encourage participation of students with low confidence & 4.37 & 0.89 \\
\hline Item 25 & talk slowly in the target language & 3.76 & 1.13 \\
\hline Item 26 & use easy words (to enhance understanding) & 3.98 & 0.95 \\
\hline Item 27 & ask questions frequently & 4.22 & 0.88 \\
\hline Item 28 & ask questions then wait for volunteers to answer & 4.24 & 0.83 \\
\hline Item 29 & ask individual students to answer questions & 4.24 & 0.88 \\
\hline
\end{tabular}


Invest. pens. crit. (ISSN 1812-3864)

Vol. 6, No. 2, mayo - agosto 2018

pp. 13-29

\begin{tabular}{|c|c|c|c|}
\hline Item 30 & give students plenty of time to answer questions & 4.16 & 0.88 \\
\hline Item 31 & treat all students fairly & 4.35 & 0.91 \\
\hline Item 32 & prepare students well for examinations & 4.33 & 0.90 \\
\hline Item 33 & give students clear grading guidelines & 4.22 & 0.93 \\
\hline Item 34 & require students to work hard during class & 4.31 & 0.87 \\
\hline Item 35 & require students to do homework & 4.28 & 0.90 \\
\hline Item 36 & possess the knowledge and ability to teach English & 4.51 & 0.75 \\
\hline Item 37 & have a good knowledge of grammar & 4.53 & 0.76 \\
\hline Item 38 & have a good knowledge of vocabulary & 4.55 & 0.78 \\
\hline Item 39 & are well prepared every lesson & 4.43 & 0.83 \\
\hline Item 40 & provide a syllabus detailing course content & 4.24 & 0.99 \\
\hline Item 41 & explain the instructional methods to the class & 4.30 & 0.86 \\
\hline Item 42 & tell students the lesson objectives before each lesson & 4.17 & 0.95 \\
\hline Item 43 & follow the syllabus & 4.29 & 0.85 \\
\hline Item 44 & make their own supplemental material & 4.30 & 0.92 \\
\hline Item 45 & start and finish the class on time & 4.39 & 0.91 \\
\hline
\end{tabular}


Invest. pens. crit. (ISSN 1812-3864)

Vol. 6, No. 2, mayo - agosto 2018

pp. 13-29

\section{References}

Anderson C (2012) Low English levels can hurt countries' progress. The New York Times. Available at: http://www.Nytimes.com/2012/10/29/world/Europe/29iht-educbriefs29.html? r $=0$

Auerbach, E., \& Burgess D. (1985). The hidden curriculum of survival ESL. TESOL Quarterly, 19(3), 475-95.

Barnes BD, Lock G (2010) The attributes of effective lecturers of English as a foreign language as perceived by students in a Korean university. Australian Journal of Teacher Education. 35(1)

Barnes BD, Lock G (2013) Student perceptions of effective foreign language teachers: a quantitative investigation from a Korean University. Australian Journal of Teacher Education. 38(2)

Chepetla T, Garcia L, Gonzalez MG, and Torres VM (2008) Enseñanza del inglés como lengua extranjera: Una Mirada desde la política del lenguaje. Memorias del 12 Encuentro Nacional de Profesores de Lenguas Extranjeras: Evolución y diversidad en la enseñanza - aprendizaje, 115-35. Departamento de Lingüística Aplicada. Centro de Enseñanza de Lenguas Extranjeras, UNAM, México.

Daraswawang P (2007) English language teaching and education in Thailand: a decade of change. In: Prescott D (ed.) English in Southeast Asia: Varieties, Literacies and Literature. Cambridge: Cambridge Scholars Publishing, 187-204.

Davies P (2009) Strategic management of ELT in public educational systems: trying to reduce failure, increase success. The Electronic Journal for English as a Second Language, TESL-EJ, 13(3):1-22.

Desai, S., Damewood, E., \& Jones, R. (2001). Be a good teacher and be seen as a good teacher. Journal of Marketing Education, 23(2), 136-144

Faranda, W.T., \& Clarke I. (2004) Student observations of outstanding teaching: Implications for marketing educators. Journal of Marketing Education, 26(3), 271-281.

Kelly, C.A., Conant, J.S., \& Smart, D.T. (1991). Master teaching revisited: Pursuing excellence from the students' perspective. Journal of Marketing Education, 13, 1-10.

Khamkhien A (2010) Teaching English speaking and English speaking tests in the Thai context: a reflection from the Thai perspective. English Language Teaching 3(1):184-90.

Krashen, S. (1982). Principles and practice in second language acquisition. London: Pergamon. 
Invest. pens. crit. (ISSN 1812-3864)

Vol. 6, No. 2, mayo - agosto 2018

pp. 13-29

Levine, G.S. (2003). Student and instructor beliefs and attitudes about target language use, first language use, and anxiety: Report of a questionnaire study. The Modern Language Journal, 87, 4660 .

Maskhao P (2002) A case study of English as a foreign language (EFL) acquisition in a post-graduate diploma course. Unpublished PhD thesis, University of Queensland, St. Lucia, Queensland.

Nilson, L. B. (2010). Teaching at its best: a research-based resource for college instructors. San Francisco, CA: Jossey-Bass.

Nonkukhetkhong K, Baldauf Jr, RB and Moni K (2006) Learner centeredness in teaching English as a Foreign Language. Paper Presented at the $26^{\text {th }}$ Thai TESOL International Conference, Chiang Mai, Thailand, 19-21 January, 1-9.

Otham N (2010) Trends in Malaysian ELT research. Presented at the MELTA conferences, 20052009. Malaysian Journal of ELT Research 6. Available at: http://www.myjurnal.my/filebank/published article/8747/Othman Normala.pdf\%207.pdf

Ramirez-Romero JL, Pamplon N (2012) Research on FLT in Mexico: main findings. In: Roux R, Mora Vazquez A, and Trejo Guzman N (eds) Research in English Language Teaching: Mexican Perspectives. Bloomington, IN: Palibrio.

Richter K (2012) The repertory grid technique within the field of applied linguistics. In: Lengeling M, Mora Pablo I (eds) Approaches to Qualitative Research. GuanaJuato: University of Guanajuato.

Salahshour, N. \& Hajizadeh, N. (2012). Characteristics of Effective EFL Instructors: Language Teachers' Perceptions Versus Learners' Perceptions. International Journal of Applied Linguistics and English Literature.

Shaaban, K \& Ghaith, G (December, 2008). Student Motivation to Learn English as a Foreign Language. Article in Foreign Language Annals.

Simpson, S., \& Mengi, E. (February, 2011). What are the characteristics of a good teacher? Paper presented at $15^{\text {th }}$ International INGED Conference: “Taking it to the Limits", Ankara, Turkey. Available at:

http://research.sabanciuniv.edu/18886/1/Perceptions of the Exemplary Teacher INGED (201 1).pdf.

Yamat H, Fisher R, and Rich S (2014) Revisiting English language learning among Malaysian children. Asian Social Science 10(3): 174-80. 